\title{
AVALIAÇÃO DA SUSCEPTIBILIDADE E RESISTÊNCIA BACTERIANA AOS AGENTES CONTROLADORES DO CRESCIMENTO DE USO HOSPITALAR E INDUSTRIAL
}

\author{
Priscylla Andrade Volkart ${ }^{1}$ \\ Matheus Souza Spagiari² \\ Delmar Bizani ${ }^{3}$
}

VOLKART, P. A.; SPAGIARI, M. S.; BIZANI, D. Estresse e lesões em atletas de esportes coletivos. Arq. Cienc. Saúde UNIPAR, Umuarama, v. 20, n. 1, p, 25-32, jan./abr. 2017.

\begin{abstract}
RESUMO: O presente trabalho tem como objetivo estudar o comportamento e a resistência de bactérias em relação a agentes químicos com ação antimicrobiana em diferentes concentrações e determinar a quantidade mínina para que ocorra a inibição dos microrganismos. Serratia marcescens, Proteus mirabilis, Pseudomonas aeruginosas, Escherichia coli, Bacillus cereus e Staphylococcus aureus, foram os microrganismos utilizados, os quais foram semeados em meio Plate Count Agar (PCA). Na sequência, aplicaram-se os testes com os agentes controladores, nas concentrações de $0,5 \%, 1,5 \%, 3,0 \%, 5,0 \%, 7,0 \%$ e 10,0 \%, e os álcoois pré-determinados. A identificação da eficácia foi definida atraves frequência e índice de inibição. Foram realizadas análises de 13 substâncias nas seis diferentes concentrações, ou seja, 468 amostras totalizadas no experimento. Com relação aos microrganismos estudados observou-se, dentre os componentes escolhidos, uma ampla resistência, mesmo em concentrações maiores. O estudo demonstrou variação de resistência e sensibilidade, sendo ácido ascórbico o agente com a maior concentração inibitória mínima e as menores concentrações foram do peróxido de hidrogênio. Considerando importância do uso desses compostos na inibição e no controle de agentes bacterianos em diferentes áreas, torna-se vital o conhecimento da amplitude de seu espectro, assim, alguns produtos, nas diluições recomendadas para uso, revelaram possuir atividade antibacteriana mais reduzida ou inexistente.
\end{abstract}

PALAVRAS-CHAVE: Bactérias. Agentes Químicos. Crescimento Bacteriano. Resistência.

\section{BACTERIAL SUSCEPTIBILITY AND RESISTANCE TO GROWTH CONTROLLING AGENTS IN HOSPITAL AND INDUSTRIAL USE}

\begin{abstract}
The present work aims at studying the behavior and bacteria resistance against chemical agents with antimicrobial action in different concentrations and determining the minimum quantity for micro-organism inhibition. This study used Serratia marcescens, Proteus mirabilis, Pseudomonas aeruginosa, Escherichia coli, Bacillus cereus and Staphylococcus aureus micro-organisms, which were seeded in Plate Count Agar (PCA) medium. After, the tests were applied with controlling agents, at concentrations of $0.5 \%, 1.5 \%, 3.0 \%$, $5.0 \%, 7.0 \%$ and $10.0 \%$, and predetermined alcohols. Effectiveness was identified by frequency and inhibition index. Analyses were carried out on 13 substances in six different concentrations, i.e., a total of 468 samples in the experiment. In relation to the studied micro-organism, a broad resistance could be observed among the chosen components, even in larger concentrations. The study presented resistance and sensitivity variation, with ascorbic acid being the agent with the greatest minimum inhibitory concentration, while hydrogen peroxide presented the lowest concentrations. Considering the importance of these compounds in inhibiting and controlling bacterial agents in different areas, it is vital to expand the knowledge on the broadness of its spectrum, since some of the products, at the recommended use dilutions, presented low or non-existent antibacterial activity.

KEYWORDS: Bacteria. Bacterial Growth. Chemical Compounds. Resistance.
\end{abstract}

\section{Introdução}

Como são relativamente comuns a presença de microrganismos em diversos ambiente, juntamente com a presença de seres humanos, as mãos são consideradas a principal via de transmissão de infecções entre pessoas e a sua correta lavagem é fundamental para proteção e prevenção de doenças. Os métodos preconizados para controlar as contaminações das superfícies de contato são importantes meios para prevenir a ação e a transmissão de microrganismos causadores de doenças (SANTOS et al., 2007). Uma maneira de diminuir a contaminação por veiculação antrópica é a utilização de antimicrobianos e controladores de crescimento de ação rápida e sem agressividade ao ambiente (CASTRO et al., 2002).

Entende-se por agentes controladores do crescimento, substâncias químicas que matam ou inibem o crescimento de microrganismos nos diferentes locais onde podem ser en- contrados. A ação de um agente controlador do crescimento pode acontecer de dois mecanismos: ação bactericida, quando ocorre a morte do organismo, ou pode também ocasionar a ação bacteriostática, quando acontece apenas a inibição do crescimento microbiano, quando este entra em contato com a substância utilizada (ANDRADE; ARAGÃO; FURLAN, 2009).

O sucesso da ação do agente controladores de crescimento depende de vários fatores, que geralmente consta como modo de uso, concentração ideal, quais microrganismos a substância atua, tempo de ação e a natureza do material a ser desinfetado. O sucesso no controle bacteriano no ambiente doméstico evita a contaminação de alimentos e também atua sobre o controle de doenças provocadas pelos microrganismos comuns no ambiente (BRAGA; FURGADO; FURLAN, 2010; REDÜ, 2014).

Entretanto, a ineficácia da ação dessas substâncias se deve a alguns fatores que podem levar ao insucesso a de- 
sinfecção química, incluindo a resistência dos microrganismos a algum determinado tipo de substância, a inativação devido à diluição do composto, antagonismos com outras substâncias e o armazenamento inapropriado das substâncias (FERREIRA, 2009; ALVES et al., 2010 e PEREIRA et al., 2015).

A susceptibilidade aos agentes químicos é avaliada por meio da determinação da concentração mínima inibitória (BRITO et al., 2000), cujo esta é a menor concentração de um agente antimicrobiano necessária para inibir o crescimento de um microrganismo após incubação in vitro (RICARDO, 2008).

O presente estudo teve como objetivo estudar o comportamento e a resistência de microrganismos frente à ação de agentes químicos controladores do crescimento e determinar quais concentrações de substâncias consideram-se melhor para retardar ou inativar o crescimento de determinados microrganismos em condições metodológicas in vitro.

\section{Material e Métodos}

A metodologia utilizada neste trabalho visou à análise qualitativa dos resultados, ou seja, a identificação de cada amostra quanto à característica da biota e a resistência de cada microrganismo. A escolha foi dentre os agentes patógenos potenciais oportunistas isolados de ambientes hospitalares. O trabalho foi realizado em quatro etapas principais: escolha e avaliação dos componentes químicos ativos em cada saneante e conservante, preparo dos materiais e incubação dos microrganismos, análise e interpretação dos resultados. Para o enfoque central da discussão deste trabalho foram escolhidos os álcoois, pela sua grande utilização como agente desinfetante.

\section{Microrganismos Utilizados}

Os microrganismos utilizados para a experimentação foram bactérias gram-positivas e gram-negativas, provenientes de isolamentos clínicos (IC) e linhagens consideradas padrão (LP), pertencentes e mantidas na bacterioteca do Laboratório de Microbiologia e Bioquímica de Microrganismos do Unilasalle/Canoas-RS. As linhagens utilizadas, bem como as características de cada espécie, estão descritas na Tabela 1. Sua escolha se justifica por fazerem parte da biota antropogênica e estarem envolvidas com infecções nosocomiais, segundo Andrade; Leopoldo; Furlan, 2006.

Tabela 1: Principais características e classificação dos microrganismos utilizados no experimento.

\begin{tabular}{l|l|l|l}
\hline \multicolumn{1}{c|}{ Bactéria } & \multicolumn{1}{c|}{ Características } & \multicolumn{1}{c}{ Condição } & \multicolumn{1}{c}{ Origem } \\
\hline $\begin{array}{l}\text { Serratia marcescens (IC) } \\
\text { Proteus mirabilis (IC) }\end{array}$ & gram-negativo, aeróbio facultativo & infecciosa & $\begin{array}{l}\text { solos, matéria orgânica, } \\
\text { alimentos }\end{array}$ \\
\hline $\begin{array}{l}\text { Pseudomonas aeruginosas } \\
\text { (IC) }\end{array}$ & gram-negativo, aeróbio & $\begin{array}{l}\text { solos, águas servidas e } \\
\text { alimentos }\end{array}$ \\
\hline $\begin{array}{l}\text { Escherichia coli (IC e LP*) } \\
\text { gram-negativo, aeróbio ou anaeróbio }\end{array}$ & $\begin{array}{l}\text { oportunista; } \\
\text { endêmica }\end{array}$ & solos, matéria orgânica \\
\hline $\begin{array}{l}\text { Bacillus cereus } \text { (IC) } \\
\text { Staphylococcultativo águas servidas, trato } \\
\text { e LP**) }\end{array}$ & gram-positivo, anaeróbio facultativo & endêmica & solos, alimentos \\
\hline
\end{tabular}

IC - isolado clínico; LP- linhagem padrão; * E. coli (ATCC 25922);**S. aureus (ATCC 29213).

\section{Preparo Dos Inóculos}

Os microrganismos foram cultivados em placas de petri contendo ágar nutriente, a fim de se obter uma cultura pura, livre de possível contaminante. Para a preparação das suspensões bacterianas foram transferidas alíquotas equivalentes a todos os microrganismos em tubos de micro centrifugação, tipo Eppendorf, contendo $1000 \mu \mathrm{L}$ de solução tampão fosfato. A partir destes tubos procedeu-se as diluições seriadas até $10^{-6}$, equivalente a $10^{8}$ a $10^{12} \mathrm{UFC} \mathrm{mL}^{-1}$, segundo INCQ (1991). Posteriormente uma alíquota de $100 \mu \mathrm{L}$ desta diluição foi depositada na superfície de placas de petri contendo Ágar Antibiótico $\mathrm{n}^{\circ} 2^{4}$ e distribuídas adequadamente por toda área total da placa, para que sua evolução fosse equivalente a todas as partes do local de semeadura.

\footnotetext{
$\overline{{ }^{4} \text { Agar antibiótico } N^{\circ} .1 \text {. Cod. } n^{\circ} 105272}$. Merck - Merck Millipore Corporation. Darmstadt, Alemanha
}

\section{Preparo das soluções contendo agentes controladores do crescimento}

As características de ação dos agentes químicos com capacidade de controlar o crescimento dos microrganismos, escolhidos para o experimento, estão descrito na Tabela 2. Todas as soluções foram preparadas em laboratório, a partir de diluições do produto concentrado. Os agentes foram escolhidos seguindo as disposições regulamentadoras estabelecidas pelas RDCs n ${ }^{\circ} 30,31$ e 34, de 16 de agosto de 2010 da ANVISA (Agência Nacional de Vigilância Sanitária) (BRASIL, 2010).

Foram pesadas e calculadas as quantidades necessárias de cada princípio ativo para a preparação quantitativa em laboratório nas concentrações escolhidas de $0,5 \%, 1,5 \%$, $3,0 \%, 5,0 \%, 7,0 \%$ e 10,0\%. Armazenadas e identificadas em frasco âmbar com o volume total de $100 \mathrm{~mL}$, sob refrigeração até a sua utilização. Os compostos álcoois utilizados nesse experimento foram o álcool etílico $32^{\circ}, 46^{\circ}, 70^{\circ}$ e $96^{\circ}$ 
GL, álcool isopropílico P.A. e álcool $70^{\circ} \mathrm{GL}$ acrescido de iodo $(0,5 \%$ p/v obtido a partir de solução mãe de iodeto metálico).

\section{Incubação e identificação das amostras}

As placas utilizadas no teste foram divididas em nove quadrantes, de maneira que cada quadrante recebeu, com auxílio de pipeta automática, uma alíquota de $10 \mu \mathrm{L}$ de cada solução.

As placas foram inoculadas com cada espécie utilizadas, por meio da semeadura pelo método Spread Plate. Após a perda de umidade da superfície foram dispensados sobre cada placa as quantidades dos agentes químicos em cada quadrante determinado. Em seguida, foram levadas para estufa a $32^{\circ} \mathrm{C}$, sobre um intervalo de tempo de 24 horas para haver o crescimento uniforme.

Os resultados foram obtidos por meio de registros da formação de halos em cada quadrante. Os halos foram medidos, com auxílio de um helômetro e transferidos para tabelas. Foi realizado um total de 478 testes, confrontando microrganismos versus concentrações dos agentes químicos, sendo 252 testes para os agentes químicos saneantes e 216 testes envolvendo os álcoois.

Todos os testes de avalição em placa foram feitos em triplicata, para tanto foi calculado a Incerteza do tipo A (Ua), que relaciona a medida de confiabilidade da medição através da análise das flutuações dos valores obtidos nas repetições.

\section{Cálculo do índice de inibição dos álcoois}

Para compor o cálculo do índice de inibição ( $\left.\mathrm{I}_{\mathrm{I}}\right)$ foi usado um controle com uma solução inerte (sem desinfetante). $\mathrm{O}$ teste foi realizado com um inóculo entre $10^{8-12} \mathrm{UCF}$ $\mathrm{mL}^{-1}$ e avaliado pelas medida dos halos de inibição em placas. A partir da leitura de todas as placas foram realizadas e calculadas as médias de cada repetição e do controle.

Assim:

$\mathrm{I}_{\mathrm{i}}=\left(\mathrm{H}_{\max }-\mathrm{H}_{\text {min }}\right)\left(\mathrm{H}_{\min }\right)^{-1}$ x 100

Onde:

$\mathrm{H}_{\max }=$ halo máximo obtido para a maior concentração (mm)

$\mathrm{H}_{\text {min }}=$ halo mínimo medido em qualquer concentração $(\mathrm{mm})$

\section{Resultados e Discussão}

\section{Teste de eficácia dos ativos (agentes) químicos}

Após o período de incubação e identificação de presença ou ausência de halos, os resultados foram divididos quanto ao percentual de concentração dos agentes químico utilizado, que se mostraram capazes de inibir o microrganismo, bem como o tamanho em milímetros ( $\mathrm{mm}$ ) do halo de inibição. Levaram-se em consideração as características tintoriais dos desinfetantes à base de Prata e Permanganato e as características morfológicas de formação das colônias de cada gênero bacteriano, como também a marca da gota de cada substância, os quais poderiam se constituir em interferentes no momento da leitura.

Tabela 2: Classificações e características dos controladores de crescimento escolhidos;

\begin{tabular}{|c|c|c|}
\hline Componente & Função geral & Utilização \\
\hline Peróxido de Hidrogênio & $\begin{array}{l}\text { Desinfetante e Esterilizante. Agente de ação } \\
\text { oxidante. Age promovendo a desnaturação } \\
\text { proteica e a ruptura da permeabilidade da } \\
\text { membrana celular. }\end{array}$ & $\begin{array}{l}\text { Usado na desinfecção de alto nível e esteriliza- } \\
\text { ção de superfícies planas e sólidas compostas } \\
\text { por materiais termossensíveis, como por exem- } \\
\text { plo, na esterilização de capilares hemodializa- } \\
\text { dores e lentes de contato. Conservante de ali- } \\
\text { mentos, bactericida e fungicida em sementes. }\end{array}$ \\
\hline $\begin{array}{l}\text { Permanganato de Potás- } \\
\text { sio }\end{array}$ & $\begin{array}{l}\text { Oxidante enérgico com ação desinfetante e } \\
\text { desodorizante. Em contato com a matéria } \\
\text { orgânica libera oxigênio. Ação superficial. } \\
\text { Dependendo da concentração pode ter ação } \\
\text { bacteriostática, adstringente, irritante ou } \\
\text { cáustica. }\end{array}$ & $\begin{array}{l}\text { Utilizado como desinfetante em desodorantes, } \\
\text { também encontrado em antissépticos (é usa- } \\
\text { do como antisséptico, em banhos, para alívio } \\
\text { sintomático de lesões cutâneas disseminadas e } \\
\text { pruriginosas). }\end{array}$ \\
\hline Ácido Acético Glacial & $\begin{array}{l}\text { Usado para corrigir alcalinidade e neutra- } \\
\text { lizar outros compostos químicos. Suave } \\
\text { agente bacteriano pela sua capacidade de } \\
\text { catalisação da hidrólise de proteínas. Ação } \\
\text { antifúngica. }\end{array}$ & $\begin{array}{l}\text { Conhecido como ácido etanoico, encontrado no } \\
\text { dia a dia mais comumente na sua forma impu- } \\
\text { ra, chamada de vinagre. Quando livre da água é } \\
\text { conhecido como ácido acético glacial. }\end{array}$ \\
\hline Fenol & $\begin{array}{l}\text { Uso restrito no tratamento de materiais não } \\
\text { críticos e superfícies fixas de alguns hospi- } \\
\text { tais. Seu poder residual, sua toxicidade e as } \\
\text { limitações de ambiente o colocaram em de- } \\
\text { suso. Agem destruindo o protoplasma com } \\
\text { ruptura da parede celular e precipitação pro- } \\
\text { teica. Possui ação bactericida, virucida, fun- } \\
\text { gicida, tuberculicida. }\end{array}$ & $\begin{array}{l}\text { O fenol é quimicamente hidroxibenzeno, Usado } \\
\text { terapeuticamente em queimaduras como ácido } \\
\text { pícrico, como indicador de } \mathrm{pH} \text { (fenolftaleína) e } \\
\text { em resinas sintéticas, como baquelite; }\end{array}$ \\
\hline
\end{tabular}




\begin{tabular}{l|l|l}
\hline Nitrato de Prata & $\begin{array}{l}\text { Sua propriedade oxidante o torna útil como } \\
\text { desinfetante; a interação de Ag com grupos } \\
\text { de enzimas e proteínas tiol desempenha um } \\
\text { papel fundamental na inativação bacteriana. } \\
\text { Bactericida para espécies gram-positivas e } \\
\text { algumas gram-negativas. }\end{array}$ & $\begin{array}{l}\text { Encontrado em alguns medicamentos na me- } \\
\text { dicina, na química para reagentes para novas } \\
\text { substâncias, na fabricação de vidros e espelhos. }\end{array}$ \\
\hline Ácido Ascórbico & $\begin{array}{l}\text { Ação antioxidante, sequestrante de radicais } \\
\text { livres - que está diretamente ligada ao siner- } \\
\text { gismo dos ácidos orgânicos. }\end{array}$ & $\begin{array}{l}\text { Conservantes alimentares, cosméticos e na pre- } \\
\text { venço da degradação da borracha. }\end{array}$ \\
\hline Ácido Bórico & $\begin{array}{l}\text { Age como desinfetante de fraca ação bacte- } \\
\text { riostática e fungistática, quando comparado } \\
\text { com desinfetantes mais modernos. Ação an- } \\
\text { tioxidante. }\end{array}$ & $\begin{array}{l}\text { Substância antisséptica e adstringente de uso } \\
\text { oftalmológico, tópico ou otológico. Associado } \\
\text { a substâncias tamponantes pode ser comerciali- } \\
\text { zado como antissépticos. }\end{array}$ \\
\hline
\end{tabular}

Fonte: (Nogaroto e Penna, 2006).

Embora não tenha sido estabelecido o quesito comparativo entre LP e IC, entre os objetivos deste trabalho, os testes mostraram que as duas linhagens padrão utilizadas ( $E$. coli ATCC 25922 e $S$. aureus ATCC 29213) não apresentaram diferenças de sensibilidade, tanto para os agentes controladores como para os alcóois, quando comparadas aos seus semelhantes isolados clínicos.

Na Tabela 3 exibem-se o comportamento de crescimento bacteriano diante de cada substância, segundo a sua concentração mínima necessária para inibição.

$\mathrm{O}$ acido bórico e o permanganato de potássio foram os agentes que exigiram concentrações inibitórias mínimas mais elevadas $(10 \%)$ para provocar inibição bacteriana. No entanto, outros agentes, como ácido acético e o peróxido de hidrogênio, foram substâncias que mostraram inibição nas menores concentrações.

Das 252 análises totais realizadas, $46,8 \%$ dos testes obtiveram resultado, ou seja, foi constatado algum halo de inibição distinguível na placa. No restante $(53,2 \%)$ não se obteve sucesso quanto à ação inibitória do agente químico, constatando-se crescimento dos microrganismos. Salienta-se que essas análises foram mantidas sob as mesmas condições laboratoriais durante todo o procedimento, não havendo interferências ou favorecimento que pudessem beneficiar isoladamente o experimento.

Tabela 3: Concentrações inibitórias mínimas controladoras do crescimento, em percentagem, segundo as espécies bacterianas testadas no experimento.

\begin{tabular}{l|c|c|c|c|c|c}
\hline \multicolumn{1}{c|}{ Substância } & S. marcecens & B. cereus & P. aeruginosa & E. coli & P. mirabilis & S. aureus \\
\hline Ácido Ascórbico & $1,5 \%$ & $3,0 \%$ & $1,5 \%$ & $5,0 \%$ & $5,0 \%$ & $3,0 \%$ \\
\hline Ácido Bórico & $10,0 \%$ & $10,0 \%$ & $10,0 \%$ & $10,0 \%$ & $10,0 \%$ & $10,0 \%$ \\
\hline Ácido Acético Glacial & $0,5 \%$ & $0,5 \%$ & $0,5 \%$ & $5,0 \%$ & $0,5 \%$ & $5,0 \%$ \\
\hline Fenol & $3,0 \%$ & $1,5 \%$ & $3,0 \%$ & $3,0 \%$ & $3,0 \%$ & $3,0 \%$ \\
\hline Nitrato de Prata & $0,5 \%$ & $0,5 \%$ & $5,0 \%$ & $0,5 \%$ & $5,0 \%$ & $1,0 \%$ \\
\hline Peróxido de Hidrogênio & $0,5 \%$ & $0,5 \%$ & $0,5 \%$ & $1,5 \%$ & $1,5 \%$ & $5,0 \%$ \\
\hline Permanganato de Potássio & $10,0 \%$ & $10,0 \%$ & $10,0 \%$ & $10,0 \%$ & $10,0 \%$ & $10,0 \%$ \\
\hline
\end{tabular}

Nas figuras 1 e 2, as placas mostram o comportamento da bactéria Staphylococcus aureus frente aos saneantes utilizados. Os halos sem crescimento observados indicam o efeito inibidor da substância sobre o microrganismo.

Dos agentes químicos utilizados, o peróxido de hidrogênio, apresentou maior efeito controlador de crescimento frente a todos os microrganismos testados, com as menores concentrações inibitórias mínimas, que para o $S$. aureus foi de $5 \%$ (fig. 1a), cujo limite máximo permitido pela ANVISA, é de $10 \%$. O peróxido de hidrogênio apresentou $83,3 \%$ de ação antimicrobiana total. Logo após, o nitrato de prata com $66,7 \%$ de ação e o ácido acético glacial com $66,7 \%$. Ácido ascórbico apresentou uma taxa de inibição de 33,3\%, tendo a sua concentração mínima inibidora de $3,0 \%$ (fig. 2c) e por último o fenol com $16,7 \%$.
Figuras 1 e 2: Placas com cultura de S. aureus. Os quadrantes: $1 \mathrm{a} ; 1 \mathrm{~b}$ e $1 \mathrm{c}$ indicam, respectivamente, as concentrações de $5 \%, 7 \%$ e $10 \%$ de peróxido de hidrogênio; e, $2 \mathrm{a}, 2 \mathrm{~b}$ e $2 \mathrm{c}$ indicam respectivamente, as concentrações de $0,5 \%, 1,5 \%$,

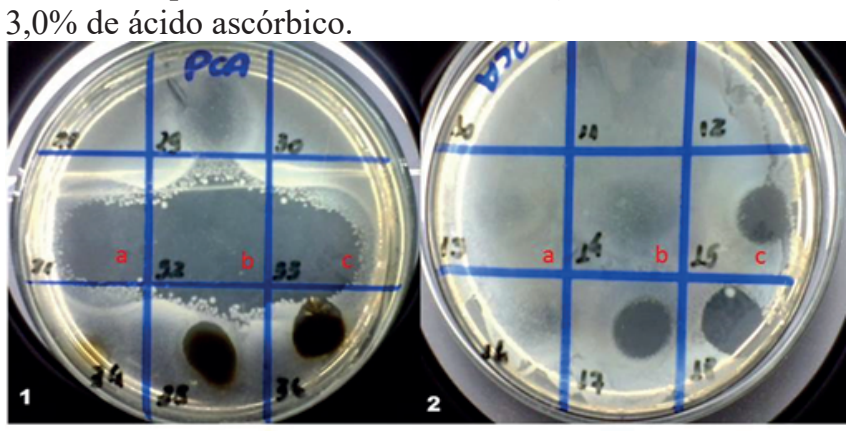

Segundo os estudo de Pereira et al. (2015) sabe-se que o peróxido de hidrogênio é um importante agente desinfetante, utilizado em assepsias de operações cirúrgicas 
pelo seu alto potencial de ruptura e permeabilidade da parede celular bacteriana, desnaturando-a e promovendo também a inibição de novas progênies. Neste trabalho, já se esperava seu resultado positivo. Já o ácido acético glacial, ou o ácido etanóico, é uma substância com capacidade cáustica, ou seja, catalisa hidrólises em proteínas. Prevalece a sua característica básica de ser considerado um agente controlador do crescimento moderado. Dentre os resultados obtidos, a seu efeito pode ter surgido pelo tempo da ação da substância sobre a parede celular bacteriana, rompendo-a e, consequentemente, alterações eletrolíticas irreversíveis. O nitrato de prata é conhecido pela sua interação com o DNA microbiano, levando os microrganismos a sofrer sérias mutações.

Bactérias gram-negativas são menos suscetíveis aos detergentes e substâncias químicas, sendo que sua parede celular é mais exigente quanto à permeabilidade e muito mais seletiva (REDÜ, 2014). Os saneantes mais eficientes para espécies gram-positivas, neste trabalho, foi o nitrato de prata, no entanto para as gram-negativas foi o peróxido de hidrogênio.

A resistência aos antimicrobianos tem sido exaustivamente estudada, com intuito de se esclarecer rotas ou mecanismos envolvidos na sua fisiologia. No entanto, a resistência bacteriana frente a produtos sanitizantes, mesmo sendo uma preocupação crescente, é pouco compreendida. Nesse sentido, destaca-se a quase inexistência de investigação científica que avalie continuadamente a eficácia antimicrobiana de desinfetantes utilizados em saúde (MOURA et al., 2011).

Alguns dos princípios ativos dos produtos desinfetantes testados revelaram, em condições laboratoriais deste experimento, possuir alguma atividade bactericida. Isto corrobora com um dos principais objetivos de um agente desinfetante, cujas substâncias ou preparações destinadas á higienização, desinfecção, desodorização, de ambientes domiciliares, coletivos e/ou públicos, é inibir o crescimento de bactérias em algum momento (BRASIL, 2001).

Conforme visto, a eficácia de cada agente controlador varia tanto na prática como no âmbito de ação desinfetante, ou seja, altera-se conforme a situação. Um bom desempenho desses agentes controladores do crescimento não só depende dessas variáveis, como também da concentração do princípio ativo. De acordo com o permitido pelas normas regulamentadoras da ANVISA, a concentração máxima é de $2 \%$, para maioria dos agentes, no entanto neste projeto foram utilizadas concentrações de princípio ativo mais elevados, portanto acima das formulações comerciais. Também é importante lembrar que a limpeza e a desinfecção de ambientes têm como meta reduzir a quantidade de microrganismos patogênicos num determinado ambiente. Considera-se que nenhum desinfetante poderá exercer sua ação com eficiência se não houver uma limpeza prévia (PEREIRA et al., 2015).

\section{Teste de eficiência de inibição dos álcoois}

A susceptibilidade aos álcoois foi verificada pela eficiência de inibição estabelecida de acordo com os resultados da medida dos halos inibitórios e a aplicação da fórmula do índice de inibição $\left(\mathrm{I}_{\mathrm{r}}\right)$.

Na Tabela 4 verifica-se o comportamento de cada bactéria frente a cada álcool correspondente. Pode-se observar que o $\mathrm{I}_{\mathrm{I}}$ variou de zero a no máximo $63 \%$, variando conforme a concentração e os microrganismos testados.

Tabela 4: Comportamento dos microrganismos frente aos diferentes álcoois e suas diluições, de acordo com o índice de inibição $\left(\mathrm{I}_{\mathrm{I}} \%\right)$ em placa.

\begin{tabular}{l|c|c|c|c|c|c}
\hline \multicolumn{1}{c|}{ Álcoois } & S. marcescens & B. cereus & P. aeruginosa & E. coli & P. mirabilis & S. aureus \\
\hline Isopropílico P.A. & 62,5 & $\mathrm{n}$ & 50 & 42,5 & 50 & 30 \\
\hline Etílico $32^{\circ} \mathrm{GL}$ & $\mathrm{n}$ & $\mathrm{n}$ & $\mathrm{n}$ & $\mathrm{n}$ & $\mathrm{n}$ & $\mathrm{n}$ \\
\hline Etílico $46^{\circ} \mathrm{GL}$ & $\mathrm{n}$ & $\mathrm{n}$ & $\mathrm{n}$ & $\mathrm{n}$ & $\mathrm{n}$ & $\mathrm{n}$ \\
\hline Etílico $70^{\circ} \mathrm{GL}$ & 27,5 & $\mathrm{n}$ & 30 & 27,5 & 30 & $\mathrm{n}$ \\
\hline Etílico $96^{\circ} \mathrm{GL}$ & 42,5 & $\mathrm{n}$ & 45 & 40 & 35 & 42,5 \\
\hline Álcool Iodado & 27,5 & $\mathrm{n}$ & 32,5 & 30 & 37,5 & 32,5 \\
\hline
\end{tabular}

n- não houve detecção de halo ou inibição, valor que corresponde à zero;

Atualmente os principais desinfetantes utilizados são álcoois, formaldeído, glutaraldeído, compostos liberadores de cloro ativo (como hipoclorito de sódio), compostos quaternário de amônio (como cloreto de benzalcônio), iodóforos e biguaninas (como clorexidina). Dentre esta gama de opções, não existe um produto que apresente todas as características desejadas, cada um possui vantagens e desvantagens que devem ser avaliadas no momento da seleção para o uso. Entretanto, os álcoois podem servir de base para muito outros químicos ou compostos ativos, incluindo os surfactantes e os extratos hidroalcoólico de vegetais, os chamados fitoquímicos (REDÜ, 2014).

Dos álcoois utilizados para os testes, em todas as 216 análises realizadas com este produto, o álcool isopropílico P.A. e o álcool etílico $96^{\circ} \mathrm{GL}$ foram os que mostraram maiores inibição de inibição de microrganismos, tendo um $I_{I}$ variando de 43 a $63 \%$. O álcool etílico $96^{\circ}$ GL teve seu efeito inibitório concentrado, entre todas as bactérias gram-positivas testadas, apenas sobre $S$. aureus, apresentando um $\mathrm{I}_{\mathrm{I}}$ em torno de $43 \%$. O álcool que mais inibiu as gram-negativas foi o álcool isopropílico P.A. Frente aos álcoois $32^{\circ}$ e $46^{\circ}$ GL não houve qualquer inibição de nenhuma bactéria. Estes resultados se devem muito, provavelmente, pela sua diluição estar abaixo do padrão considerado como bactericida ou, até mesmo, antisséptico.

O álcool etílico e o isopropílico possuem atividade contra bactérias na forma vegetativa, vírus envelopados (p. ex.: vírus causadores da influenza, das hepatites B e C e HIV), micobactérias e fungos. Não apresentam ação contra esporos e vírus não envelopados (p. ex.: vírus da hepatite A e Rinovírus), caracterizando-se como desinfetante e antisséptico, porém sem propriedade esterilizante. Dentre todas as 
características, ambos possuem $\mathrm{I}_{\mathrm{I}}$ bastante significativo para os diferentes grupos bacterianos de importância industrial e médica. Em geral, o álcool isopropílico é considerado mais eficaz contra bactérias, enquanto o álcool etílico é mais potente contra vírus (SANTOS, et al., 2002).

O álcool $70^{\circ} \mathrm{GL}$ considerado ideal, pela sua característica bactericida e de inibição da síntese bacteriana, não mostrou resultados satisfatórios, mesmo quando comparado ao álcool $96^{\circ}$ GL. Segundo (SANTOS, et al., 2007) álcool $96^{\circ} \mathrm{GL}$ por característica de maior volatilidade e solubilização dos ácidos graxos, torna-se mais difícil a penetração via membrana celular, não tendo assim o mesmo rendimento sobre a bactéria.

Dentre as bactérias testadas, a revelação foi do $B$. cereus, que por ser gram-positivo não possuir parede externa, deveria ser mais suscetível à ação de agentes químicos. Neste teste, frente aos álcoois, apresentou maior resistência, apesar de ter-se mostrado relativamente sensível aos demais agentes químicos. Uma das características peculiares deste microrganismo é ter um histórico de patogenias relativamente frequentes, como síndromes toxigênicas alimentares. Pela sua grande ocorrência em uma ampla variedade de alimentos, como peixes, carnes, leites vegetais, produtos à base de massas, queijo e batata e pela sua facilidade de proliferação à temperatura ambiente e grande possibilidade de sobrevivência à fervura, o B. cereus, desponta como grande interesse para avaliação de resistência. Sabendo-se, com base na primeira etapa deste experimento, este bacilo, foi suscetível em mais da metade dos componentes químicos abaixo de $2 \%$, conforme o que a legislação permite no mercado e, ainda, moderadamente resistente aos outros restantes. Porém, sua alta tolerância diante dos álcoois indica maior capacidade de resistência dentre todas as bactérias testadas. Sendo este microrganismo facilmente ligado as toxinfecções alimentares e mais resistentes frente aos álcoois, pode-se entender que representa maior risco sanitário.

O comportamento do $S$. aureus foi um dos mais resistentes do grupo. Em todas as etapas do experimento, este se mostrou mais resistente, p. ex., que a Serratia marcescens, gram-negativo, de estrutura mais complexa e seletiva. Apesar da pequena diferença de comportamento, ambas mostraram-se moderadamente resistentes tanto na primeira quanto na segunda etapa. O $S$. aureus é responsável por infecções relativamente simples da pele e mucosas até endocardite e pneumonia mais sérias. $S$. marcescens, está envolvida com infecções no trato respiratório, urinário, pele, feridas cirúrgicas e podem colonizar também o sangue (TORTORA; FUNKE; CASE, 2006).

A E. coli, gram-negativo, oportunista e endêmica, também apresentou padrão de resistência considerável, podendo-se observar comportamento semelhante ao da $S$. marcescens e $S$. aureus na primeira etapa com os agentes químicos e na segunda, com álcoois.

Sendo gram-negativa demostra maior dificuldade de ocorrência de ruptura de membrana celular e pela sua característica de adaptação e superação de condições adversas, essa bactéria, demonstrou ampla capacidade de resistência aos álcoois 32 e $46^{\circ} \mathrm{GL}$, porém respondeu mais positivamente ao álcool isopropílico P.A. e ao nitrato de prata. A $E$. coli é responsável por infecções, diarreias, cistite, meningite e até casos mais graves, com a linhagem identificada como
E. coli $\mathrm{O} 104: \mathrm{H} 4$, que há algum tempo provocou um surto na Europa, ocasionando uma colite hemorrágica e síndrome hemolítico-urêmica (REDÜ, 2014).

Porém, diante dos padrões microbiológicos obtido neste trabalho, nem todos os álcoois, muito discutidos para uso frente a microrganismos de importância industrial ou hospitalar, não atingiram seus objetivos estabelecidos nos padrões da pesquisa, havendo desenvolvimento microbiano mesmo após contato. Para Santos et al. (2007) isto indica que essas espécies microbianas então em frequente mudança de resistência, devido ao fator "pressão de modificação" imposto pelo meio ambiente.

Dos álcoois, o álcool etílico $70,96^{\circ} \mathrm{GL}$, iodado e isopropílico P.A. se mostraram eficientes inibidores. Existem várias razões para o álcool etílico ser inibidor, uma vez que é amplamente citado em literaturas como sendo base para outros desinfetantes e ter aprovação do Controle de Doenças e Prevenção (CDC), além de preencher os quesitos normativos do Comitê Europeu de Normalização (CEN) (BRASIL, 2007; CDC, 2008; ECS, 2009).

Os motivos são devido ao álcool precipitar proteínas teciduais que normalmente estão presentes no sangue e na saliva, e podem ser carregadas pelas mãos, contaminando facilmente superfícies. Outra razão físico-química, que explica isso seria sua rápida evaporação, que limita sua atividade sobre vírus e bactérias com cobertura proteica (MOURA et al., 2011).

Vale salientar que todos os álcoois utilizados nos testes não sofreram diluições com outros solventes, ou seja, foram utilizados em suas concentrações propostas em metodologias oficiais. Quanto aos materiais em geral (detergentes, halogênios e álcool) ainda cabe lembrar, que na desinfecção industrial, hospitalar ou doméstica na maioria das vezes, estes ativos ainda são possivelmente mais diluídos, diminuindo consideravelmente o poder de sua ação (REDÜ, 2014).

De acordo com Timenetsky (1990) a atividade antimicrobiana de um produto desinfetante não é a real capacidade de desinfecção de um ambiente que, por sua vez, pode ter diversos fatores interferentes, alguns até imprevisíveis, prejudicando a atividade antimicrobiana de um composto ativo. Por esta razão, os testes padronizados ou não são discutíveis e não existe um único método de avaliação microbiológica que considere todas as variáveis no contexto geral da desinfecção.

Nas figuras 3 e 4 podem-se observar halos de inibição em placas das bactérias Serratia marcescens e Pseudomonas aeruginosas, respectivamente, em que ambas mostraram-se sensíveis aos álcoois isopropílico P.A., etílico $96^{\circ}$ GL, etílico $70^{\circ} \mathrm{GL}$ e iodado. Nota-se que os álcoois $32^{\circ} \mathrm{GL}$ e $46^{\circ}$ GL não foram capazes de inibir o crescimento microbiano. 
Figuras 3 e 4: Placas de cultura de $S$. marcescens e $P$. aeruginosas, respectivamente, frente a diferentes álcoois. Letras: a) Álcool isopropílico P.A.; b) Álcool Etílico $70^{\circ} \mathrm{GL}$; c) Álcool iodado; d) Álcool Etílico 96 GL.

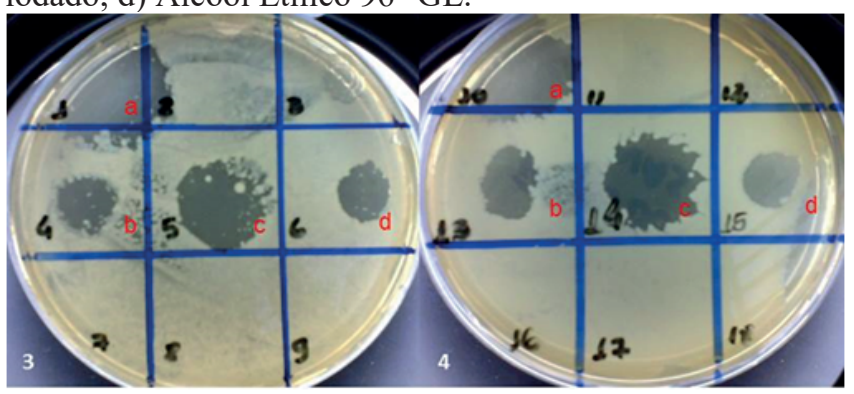

Atribui-se ao fato dos saneantes utilizados não gerar inibição, os fatores decorrentes de capacidade de solubilização, ação e características bactericidas e orgânicas baixas, que direta ou indiretamente tenham influenciado na sua eficácia e desempenho. Vale ressaltar que resultados ainda mais específicos poderiam ser obtidos após reproduções dos testes, minimizando interferente.

De acordo com Santos et al. (2010) a resistência de cada bactéria está diretamente ligada ao seu tempo de exposição frente a uma determinada concentração de desinfetante. Nos experimentos realizados in vitro, com o álcool $70^{\circ} \mathrm{GL}$, este se apresentou ineficaz em 30 segundos de exposição ao $S$. epidemidis, seguido dos demais agentes utilizados, que também apresentaram considerável tempo para inibir outros microrganismos. Rutala; Weber (2004) definem bactérias do gênero Staphylococcus, como sendo circunstancialmente resistentes aos antibióticos e desinfetantes, principalmente o $S$. aureus. De acordo com esses autores, que avaliaram a suscetibilidade desse microrganismo frente aos desinfetantes, descobriram que eles são sensíveis à sua ação e também ficam inutilizados, após em média 30 segundos e 5 minutos de exposição. Já, de acordo com Santos et al. (2007 e 2010), que ao adicionar em tubos de ensaio, contendo desinfetantes, uma suspensão com concentrações até $10^{5}$ UFC mL-1 de bactérias $S$. aureus e $E$. coli, após iniciada a contagem precisaram de 2,5 a 15 minutos para sua inativação total, predizendo que a substância atingira seu objetivo. Comparado os resultados observados às conclusões dos autores é possível afirmar que amplas variações de resistência podem ser observadas conforme a metodologia aplicada.

\section{Considerações Finais}

Partindo dos resultados encontrados, pode-se concluir que as tendências dos desinfetantes de uso geral, disponíveis no mercado, podem ter seu espectro de eficácia alterado conforme as práticas de uso, mesmo levando em conta as legislações vigentes.

Este estudo vem corroborar com a tendência mundial no uso de controladores de crescimento, principalmente com relação aos álcoois, provando que uso rotineiro, isoladamente, na assepsia das mãos é mais eficaz do que a lavagem prévia com água e sabão. No Brasil, o álcool é amplamente utilizado como desinfetante, mas a ideia de substituir a lavagem das mãos pela antissepsia com álcool, ainda é pouco aceita. Os Estados Unidos, apesar de não possuírem tradição na utilização do álcool para estes fins, vêm se rendendo aos estudos que comprovam a eficácia desta substância como alternativa à lavagem das mãos.

Um aspecto importante que embasou este trabalho, também leva a concluir que as mudanças de método e de materiais utilizados influenciam amplamente no resultado, interferindo nos dados finais e que, mesmo em casos nos quais as características ambientais são diferentes, apresentam resultados semelhantes.

Embora este estudo não tenha revisado variações metodológicas, torna-se suficiente para concluir pelas evidências a necessidade de elaborar protocolos de acompanhamentos e testes de viabilidade de produto para cada setor em particular.

\section{Referências}

ALVES, A. P. et al. Análise asséptica em ambientes de uso comum no campus da Universidade Castelo Branco.

Revista Eletrônica Novo Enfoque, v. 11, n. 11, p. 21 - 26, 2010.

ANDRADE. D.; LEOPOLDO, V.C.; HAAS, V.J. Ocorrência de bactérias multirresistentes em um centro de terapia intensiva de Hospital Brasileiro de Emergências.

Revista Brasileira de Terapia Intensiva, v. 18, n. 1, p. 27-33, 2006.

\section{ANDRADE, D.C.C.; ARAGÃO C.C.V.; FURLAN, C.M.} Avaliação da estabilidade físico-química da solução de hipoclorito de sódio a $0,5 \%$, utilizada pela farmaUSCS, e de sua eficácia bactericida sobre Staphylococcus aureus e Escherichia coli. Revista Brasileira de Ciências da Saúde, v. 7, n. 21, p. 16 - 25, jul./set. 2009.

BRASIL, Agência Nacional de Vigilância Sanitária ANVISA. Resolução RDC No 14, de 28 de fevereiro de 2007. Aprova o regulamento Técnico para Produtos Saneantes com Ação Antimicrobiana harmonizado no âmbito do Mercosul através da Resolução ao GMC, $\mathrm{n}^{\circ}$ 50/05, que consta em anexo à presente Resolução. Diário Oficial da República Federativa do Brasil. Brasília, DF, 5 mar. 2007.

BRASIL. Agência Nacional de Vigilância Sanitária ANVISA. Resolução RDC n ${ }^{\circ}$ 34, de 16 de agosto de 2010. Diário Oficial da República Federativa do Brasil, Brasília, DF, 18 ago. 2010.

BRASIL. Agência Nacional de Vigilância Sanitária ANVISA. Resolução RDC nº 115 (2001). Dispõe sobre atualização de normas e procedimentos referentes ao registro de produtos Saneantes Domissanitários com ação antimicrobiana. Diário Oficial da República Federativa do Brasil, Brasília, DF, 2001. - Disponível: <http://www. anvisa.gov.br/saneantes/legis/especifica/desinfetante. htm>Acesso em: 22 mar. 2016.

BRAGA, S. M. S.; FURTADO, V. C. de S.; FURLAN, C. M. Avaliação in vitro da eficácia bactericida de desinfetantes de uso geral frente a amostras de Staphylococcus aureus e 
Escherichia coli. Revista Científica FEPI, v. 2, 2010.

BRITO, M .A. V. P. et al. Concentração mínima inibitória de dez antimicrobianos para amostras de Staphylococcus aureus isoladas de infecção intramamária bovina. Arq. Bras. Med. Vet. Zootec., v. 53, n. 5, p. 531-537, 2000.

CASTRO, M. S. et al. Tendências na utilização de antimicrobianos em um hospital universitário, 1990-1996.

Revista Saúde Pública, v. 36, n. 5, p. 553-558, 2002.

CENTERS FOR DISEASE CONTROL AND

PREVENTION (CDC). Guidelines for Environmental

Infection Control in Health-Care Facilities, 2008, 158p.

Disponível em: <http://www.cdc.gov/hicpac/pdf/guidelines/ eic_in_HCF_03.pdf $>$ Acesso em: 25 mai 2012.

\section{EUROPEAN COMMITTEE FOR STANDARDIZATION} (ECS). EN 1276:2009. Chemical disinfectants and antiseptics: Quantitative suspension test for the evaluation of bactericidal activity of chemical disinfectants and antiseptics used in food, industrial, domestic and institutional areas - Test method and requirements (phase 2, step 1). Brussels: European Committee for Standardization; 2009.

FERREIRA, C. A. Avaliação do efeito antibacteriano sobre desinfetantes utilizados para limpeza do bloco da saúde "s" da Universidade do Extremo Sul Catarinense (UNESC) Criciúma - SC. 2009. 36 f. Monografia de Conclusão de Curso - Departamento de Farmácia, Universidade do Extremo Sul Catarinense. Criciúma, 2009.

\section{INSTITUTO NACIONAL DE CONTROLE DE} QUALIDADE EM SAÚDE (INCQ). Manual de saneantes. Rio de Janeiro: Fundação Oswaldo Cruz; 1991.

MOURA, A. C. et al. Perfil de resistência microbiana aos principais sanitizantes utilizados em frigoríficos da cidade de cascavel, PR. Revista Higiene Alimentar, v. 25, 2011.

NOGAROTO, S. L. E.; PENNA, T. C. V. Desinfecção e Esterilização, São Paulo: Atheneu, 2006.

PEREIRA, S. S. P. et al. Desinfecção com hipoclorito de sódio em superfícies ambientais hospitalares na redução de contaminação e prevenção de infecção: revisão sistemática. Revista da Escola de Enfermagem da USP, v. 49, n. 4, p. 681-688, 2015.

REDÜ, J. F. M. Atividade biocida de desinfetantes e fitoquímicos frente a fungos isolados de animais silvestres mantidos em centro de recuperação. 2014. 97 f. Dissertação (Mestrado em Ciências Veterinária). UFRGS. Porto Alegre. 2014.

RICARDO, S. B. Elevação de MIC para Vancomicina no Staphylococcus aureus. Revista Prática Hospitalar, v. 60, 2008.

RUTALA, W. A.; WEBER, D. J. The benefits of surface disinfection. Am J Infect Control. v. 32, p. 226-231, 2004.

SANTOS, A. A. M. et al. A importância do álcool no controle de infecções em serviços de saúde. Revista de Administração em Saúde, v 4, n. 16, p. 7-14, 2002.

SANTOS, L. R. et al. Eficácia de desinfetantes e antisépticos empregados no hospital veterinário da UPF (HVUPF) Brasil. Revista da FZVA, v. 14, n. 2, p. 156-164, 2007.

SANTOS, L. R. et al. Contaminação ambiental em um hospital veterinário e perfil de suscetibilidade a antimicrobianos das bactérias isoladas. Ciência Animal Brasileira, Goiânia, v. 11, n. 2, p. 384-389, 2010.

TIMENETSKY, J. Avaliação microbiológica de desinfetantes químicos de uso doméstico. Revista Saúde pública, v. 24, n. 1, p. 47-50, 1990.

TORTORA, G. J.; FUNKE, B. R.; CASE, C.L.

Microbiologia. 8. ed. Porto Alegre:Artmed, 2006, p. 183200; 459-460; 590-592.
Recebido em: 17/06/2016 Aceito em: 09/12/2016 